\title{
Pengaruh Interval Waktu Pemberian Pupuk Organik Cair Berbahan Baku Keong Mas Terhadap Pertumbuhan dan Produksi Hijauan Pennisetum purpureum cv. Mott
}

\author{
(Effect Of Time Interval Of Liquid Organic Fertilizer \\ Made From Raw Of Golden Snail On The Growth And \\ Forage Production of Pennisetum purpureum cv. \\ Mott)
}

\author{
Silvester Muga Sada ${ }^{1}$, Bernadete Barek Koten ${ }^{1}$, Bernadus Ndoen ${ }^{2}$, Agustinus Paga ${ }^{1}$, Paskalis \\ Toe $^{1}$, Redempta Wea ${ }^{2}$, Ariyanto. \\ ${ }^{1}$ Program Studi Teknologi Pakan Ternak dan ${ }^{2}$ Program Studi Produksi Ternak \\ Jurusan Peternakan, Politeknik Pertanian Negeri Kupang \\ Jl. Prof. Dr. Herman Yohanes Lasiana Kupang P.O.Box. 1152, Kupang 85011 \\ Email: mugasilvestersada@gmail.com
}

\begin{abstract}
The research with aim to assessing the effect of giving time interval of organic liquid fertilizer made golden snail aplle on growth and forage production Pennisetum purpureum cv. Mott, has been held for 3 months at the Kupang State Agricultural Polytechnic gardens forage at Oesao. The study was designed by Randomized Block Design, with 5 treatments and 5 block, which consists of the P0: without organic liquid fertilizer, P5: every 5 days, P7: every 7 days, P9: every 9 days, P11: every 11 days. The variables are number of shoots (number/ week), high gain $(\mathrm{cm} /$ week), production of fresh weight (tons/ ha), dry matter production of forage (tons/ ha). Analysis of variance showed that the interval timing of organic liquid fertilizer made of snails no significant effect $(P>0.05)$ to number of shoots, high gain, fresh weight production of forage, and dry matter production of forage. The average of number of shoots are 10.11/ week (P0: 10.46; P5: 11.35; P7: 10.41; P9: 9.39; P11: 8.94), the increase plant height $20.90 \mathrm{~cm} /$ week (P0: 21.06; P5: 22.01; P7: 21.20; P9: 20.61; P11: 19.60), 53.32 tonnes / ha the fresh production of forage (P0: 53.62; P5: 57.71; P7: 49.39; P9: 55.18; P11: 50.71), 7.73 tonnes/ ha of dry matter of forage (P0: 7.72; P5: 8.80; P7: 7.17; P9: 7.68; P11: 7.26). It was concluded that the growth and forage production of Pennisetum purpureum cv. Mott is not be effected of effect of time interval of liquid organic fertilizer made from raw of golden snail.
\end{abstract}

Keywords: Fresh weight production, liquid fertilizer, Pennisetum purpureum cv. Mott, plant height, the number of shoots, the production of dry weight.

\section{PENDAhuluan}

Pennisetum purpureum cv. Mott merupakan jenis hijauan yang memiliki produksi yang tinggi, mudah dibudidayakan, memiliki kandungan nutrisi yang cukup baik dan sangat disukai oleh ternak ruminansia. Produktivitas rumput Pennisetum purpureum cv. Mott pada musim hujan dapat mencapai 150 ton/ha dengan umur pemanenan 3 bulan (Budidayapetani, 2015). Yasin, $d k k$., (2003) yang dikutip Wildan (2015) menyatakan bahwa kandungan nutrisi rumput Pennisetum purpureum cv. Mott diantaranya: lemak batang $0.91 \%$, lemak daun $2.72 \%$, protein kasar (PK) batang $8.1 \%$, PK daun $14.35 \%$, kecernaan daun $72.68 \%$, kecernaan batang $62.56 \%$, PK $14 \%$.

Produktivitas rumput Pennisetum purpureum cv. Mott juga membutuhkan bahan organik yang berasal dari tanah. Dari tanah, tanaman mendapatkan unsur hara yang diperlukan untuk proses fotosintesis yang berdampak pada pertumbuhan dan produksi tanaman pakan. Persediaan unsur hara yang rendah dalam tanah, akan menghambat pertumbuhan dan produksi tanaman pakan. Upaya yang dapat dilakukan untuk meningkatkan nilai hara dalam 
Silvester Muga Sada, Bernadete Barek Koten, Bernadus Ndoen, Agustinus Paga, Paskalis Toe, RedemptaWea, Ariyanto. Pengaruh Interval Waktu Pemberian Pupuk Organik Cair Berbahan Baku Keong Mas Terhadap Pertumbuhan dan Produksi Hijauan Pennisetum purpureum cv. Mott

tanah adalah dengan penambahan pupuk organik cair (POC). Pemberian POC ini dapat meningkatkan produktitas hijauan tanaman pakan. Toe et al. (2016) melaporkan bahwa POC berbahan feses babi meningkatkan pertambahan tinggi tanaman dari 9,75 $\mathrm{cm} /$ minggu menjadi 10,17 $\mathrm{cm} /$ minggu dan meningkatkan produksi bahan segar hijauan dari 20,43 ton/ha menjadi 21,37 ton/ha.

POC dapat dibuat dari molusca air tawar berupa keong mas (Pomaceae canaliculata lammarck) yang juga dikenal sebagai hama tanaman padi. Hal ini karena, keong mas mempunyai kandungan protein yang sangat tinggi sekitar $57,67 \%$ atau setara dengan 9,23\% N, (Suktikno, 2011), yang dapat dipertimbangkan sebagai sumber nitrogen $(\mathrm{N})$ utama untuk pertumbuhan tanaman. Frekuensi pemberian pupuk berpengaruh terhadap unsur hara dalam tanah dan pemanfaatan unsur hara pada tanaman. Waktu aplikasi pupuk yang tepat akan meningkatkan pertumbuhan serta produksi tanaman. Tetapi pemberian pupuk dengan interval waktu yang terlalu sering berdampak pada pemborosan pupuk serta berdampak negatif pada tanaman berupa kelayuan. Sebaliknya, bila interval pemupukan terlalu jarang menyebabkan kebutuhan hara tanaman kurang terpenuhi (Soetejo dan Kartasapoetra, 1991).

Tujuan dari penelitian ini yaitu untuk mengkaji pertumbuhan dan produksi hijauan rumput Pennisetum purpureum cv. Mott dengan interval waktu pemberian POC keong mas yang berbeda serta waktu interval terbaik dari pemberian POC keong mas terhadap pertumbuhan dan produksi hijauan rumput Pennisetum purpureum cv. Mott.

\section{METODE PENELITIAN}

Penelitian telah dilaksanakan di Kebun Hijauan Makanan Ternak Oesao, milik Politeknik Pertanian Negeri Kupang selama 5 bulan dari bulan Oktober 2106 - Februari 2017.

Bahan yang digunakan adalah pols rumput Pennisetum purpureum cv. Mott, POC keong mas, pupuk NPK, air bersih untuk menyiram tanaman, lahan $198 \mathrm{~m}^{2}$.

Alat yang digunakan adalah seperangkat alat pertanian, timbangan digital merk Ohaus kapasitas $2 \mathrm{~kg}$ dan timbangan gantung merek Camry kapasitas $5 \mathrm{~kg}$ yang digunakan untuk menimbang sampel rumput Pennisetum purpureum cv. Mott, meteran yang digunakan untuk mengukur tinggi tanaman serta lebar dan panjang plot.

\section{Prosedur Penelitian}

Tahap persiapan meliputi, membuat plot dengan ukuran $2 \mathrm{~m}$ x 1,6 $\mathrm{m}$ dan jarak antar plot 0,5 m. Pembuatan POC keong mas dengan cara: mengolah keong (daging dan cangkang) menjadi tepung keong mas, mencampur 8 liter air, 500 gram tepung beras dan $320 \mathrm{cc} \mathrm{EM}_{4}$ kemudian endapkan semalam (12 jam), 800 gram gula merah diencerkan dengan cara ditumbuk dan dilarutkan dalam $500 \mathrm{ml}$ air panas, mencampur gula merah dengan 4 liter air kelapa tua dalam satu wadah, mencampur semua bahan dengan $1 \mathrm{~kg}$ tepung keong mas menjadi satu, aduk hingga merata, tutup rapat ember dengan plastik dan dibalut dengan plakban, bagian atas diberi lubang sesuai ukuran selang plastik, kemudian selang dimasukan ke lubang tersebut, menghubungkan selang tersebut dengan botol air kemasan yang telah diisi air setengahnya, tunggu proses fermentasi secara an-aerob selama \pm 21 hari, pembuatan dinilai berhasil jika hasil fermentasi mengeluarkan bau harum yang khas. Penanaman dilakukan dengan cara pols pada setiap titik tanam dibenamkan sebanyak 2 anakan perlubang, dengan jarak tanam 0,8 m x $1 \mathrm{~m}$. Pemberian pupuk NPK untuk membantu pertumbuhan awal rumput Pennisetum purpureum cv. Mott yang dilakukan 10 hari setelah penanaman rumput Pennisetum purpureum cv. Mott dengan dosis $100 \mathrm{~kg} / \mathrm{ha}(2,40$ g/titik tanam), setelah umur tanam 21 hari, tanaman diberi perlakuan dengan menggunakan POC keong mas 1 liter : 10 liter air, dengan dosis yang sama (250 $\mathrm{ml} /$ titik tanam) dan interval waktu yang berbeda sampai akhir penelitian. Tahapan pemeliharaan meliputi penyiraman yang dilakukan setiap 1 hari sekali dan penyiangan. Pengukuran tinggi serta perhitungan jumlah anakan yang dilakukan seminggu sekali dimulai saat tanaman berumur 21 hari hingga panen.

Setelah tanaman berumur 60 hari, tanaman dipanen untuk melihat produksi bahan segar dan produksi bahan kering dari rumput Pennisetum purpureum cv. Mott. Kegiatan ini dilanjutkan dengan preparasi sampel untuk analisis laboratorium. 


\subsection{Rancangan Percobaan}

Penelitian menggunakan rancangan percobaan yang didesain berdasarkan Rancangan Acak Kelompok (RAK), dengan 5 perlakuan dan 5 kelompok ulangan. Di mana perlakuan terdapat dalam setiap kelompok dengan model matematika menurut Gasperz (1994) dengan perlakuan yang dicobakan adalah:

P0 : tanpa pupuk cair

P5 : pupuk cair diberikan setiap 5 hari sekali

P7 : pupuk cair diberikan setiap 7 hari sekali

P9 : pupuk cair diberikan setiap 9 hari sekali

P11 : pupuk cair diberikan setiap 11 hari sekali

\subsubsection{Analisis Data}

Data yang diperoleh dalam penelitian ini dianalisis dengan analisis varians berdasarkan rancangan acak kelompok (RAK) (Gasperz, 1994).

\section{HASIL DAN PEMBAHASAN Gambaran Umum Penelitian}

Tanah yang digunakan sebagai media tanam adalah jenis tanah vertisol. Berdasarkan hasil analisa unsur hara tanah pada lokasi penelitian sebagai berikut: pH $\left(\mathrm{H}_{2} \mathrm{O}\right) 7,4$; C Org. (Kurmish) 1,90\%; N Total (Kejdhal) 0,11\%; P2O5 (Olsen) 15,23 ppm; K (Morgan) 0,97 Me/100 gr; Pasir 6,28\%, debu: $71,96 \%$, liat: $21,96 \%$. Hasil analisa POC keong mas pH $\left(\mathrm{H}_{2} \mathrm{O}\right) 7,3 ; \mathrm{N}$ Total (Kejdhal) $1,22 \% ; \mathrm{P}_{2} \mathrm{O}_{5}$ (Olsen) 34,45 ppm; K (Morgan) 0,07 Me/100 gr. Suhu lingkungan yang diukur saat penelitian yaitu $32,2{ }^{\circ}$ C. Bibit rumput Pennisetum purpureum cv. Mott yang digunakan dalam penelitian ini diperoleh dari BPTP Sulawesi Utara, yang dikirim oleh Bapak Aryanto. Panjang akar yang diukur setelah panen yaitu $115 \mathrm{~cm}$ dengan panjang tajuk $80-100 \mathrm{~cm}$. Hasil pengamatan, rumput Pennisetum purpureum cv. Mott menunjukkan pertumbuhan yang baik dan yang mendapat POC keong mas dengan interval 5 hari sekali (P5) menunjukkan pertumbuhan yang lebih baik dengan warna daun yang lebih hijau. Selain itu pada tanah yang mendapat perlakuan POC keong mas terlihat lebih gembur. Rerata presentase berat batang tanaman rumput Pennisetum purpureum cv. Mott yang ditimbang setelah penelitian $51 \%$ degan rerata setiap perlakuan P0: $52 \%$, P5: $54 \%$, P7: 49\%, P9: 49\%, P11: 52\%, sedangkan rerata daun rumput Pennisetum purpureum cv. Mott $4 \%$ dengan rerata setiap perlakuan P0: $48 \%$, P5: $46 \%$, P7: 51\%, P9: 51\%, P11: 48\%. Jumlah bunga rumput
Pennisetum purpureum cv. Mott untuk masingmasing perlakuan, yang dihitung setelah pemanenan pada umur 60 hari yaitu P0: 3 buah, P5: 12 buah, P7: 7 buah, P9: 3 buah dan P11: 1 buah.

\section{Pengaruh Interval Waktu Pemberian Pupuk Organic Cair Berbahan Baku Keong Mas Terhadap Pertumbuhan dan Produksi Pennisetum purpureum cv. Mott}

Tabel1. Pengaruh Interval Waktu Pemberian Pupuk Organic Cair Berbahan BaKu KeOng Mas TerhadaP PERTUMBUHAN DAN PRODUKSI PENNISETUM PURPUREUM CV. MotT.

\begin{tabular}{|c|c|c|c|}
\hline $\begin{array}{c}\text { Perlakua } \\
\text { n }\end{array}$ & $\begin{array}{l}\text { Pertambah } \\
\text { an tinggi } \\
\text { tanaman }\end{array}$ & $\begin{array}{l}\text { Pertambahan } \\
\text { jumlah tunas } \\
\text { (jumlah/mingg }\end{array}$ & $\begin{array}{l}\text { Produk Produk } \\
\text { si bobot si bobot } \\
\text { segar kering }\end{array}$ \\
\hline & $\begin{array}{c}(\mathrm{cm} / \mathrm{mingg} \\
\mathrm{u})\end{array}$ & u) & $($ ton $/ \mathrm{ha})(\mathrm{ton} / \mathrm{h}$ \\
\hline P0 & $21.06^{\mathrm{ns}}$ & $10.46^{\mathrm{ns}}$ & $53.62^{\mathrm{ns}} 7.72^{\mathrm{ns}}$ \\
\hline P5 & $22.01^{\mathrm{ns}}$ & $11.35^{\mathrm{ns}}$ & $57.71^{\mathrm{ns}} 8.80^{\mathrm{ns}}$ \\
\hline P7 & $21.20^{\mathrm{ns}}$ & $10.41^{\mathrm{ns}}$ & $49.39^{\mathrm{ns}} 7.17^{\mathrm{ns}}$ \\
\hline P9 & $20.61^{\mathrm{ns}}$ & $9.39^{\mathrm{ns}}$ & $55.18^{\mathrm{ns}} 7.68^{\mathrm{ns}}$ \\
\hline P11 & $19.60^{\mathrm{ns}}$ & $8.94^{\mathrm{ns}}$ & $50.71^{\mathrm{ns}} 7.26^{\mathrm{ns}}$ \\
\hline
\end{tabular}

Berdasarkan data penelitian pada Tabel 1. menunjukkan bahwa pertambahan jumlah tunas tertinggi terdapat pada perlakuan interval waktu pemberian POC keong mas 5 hari sekali (P5) sebesar 11,35 tunas/minggu dan terendah terdapat pada perlakuan interval waktu pemberian POC keong mas 11 hari sekali (P11) sebesar 8,94 tunas/minggu. Rataan pertambahan jumlah anakan rumput Pennisetum purpureum cv. Mott yang diberikan POC keong mas sebesar 10,11 tunas/minggu. Rata-rata pertambahan jumlah tunas pada P0 sebesar 10,46 jumlah/minggu, lebih tinggi dari perlakuan P7: 10,41 jumlah/minggu, P9: 9,39 jumlah/minggu dan P11: 8,94 jumlah/minggu. Jumlah tunas tersebut lebih tinggi dari penelitian Syamsudin dkk. (2015) dengan rata-rata pertambahan jumlah tunas rumput Pennisetum purpureum cv. Mott sebesar 4,75 tunas dengan perlakuan yang dicobakan adalah efek pemberian cendawan mikoriza terhadap pertumbuhan dan produksi bahan kering rumput Pennisetum purpureum cv. Mott dalam kondisi cekaman kekeringan. Analisis varians menunjukkan bahwa interval waktu pemberian POC berbahan baku keong 
Silvester Muga Sada, Bernadete Barek Koten, Bernadus Ndoen, Agustinus Paga, Paskalis Toe, RedemptaWea, Ariyanto. Pengaruh Interval Waktu Pemberian Pupuk Organik Cair Berbahan Baku Keong Mas Terhadap Pertumbuhan dan Produksi Hijauan Pennisetum purpureum cv. Mott

mas tidak memberikan pengaruh nyata $(\mathrm{P}>0,05)$ terhadap pertambahan jumlah tunas hijauan rumput Pennisetum purpureum cv. Mott. Pengaruh berbeda tidak nyata tersebut dipengaruhi oleh, konsentrasi POC keong mas yang diberikan terlalu rendah, sehingga unsur hara yang disumbangkan untuk tanaman sedikit dan ini yang membuat kebutuhan tanaman akan unsur hara kurang terpenuhi. Hal tersebut sesuai dengan pendapat Djiwosaputro (1990) yang dikutip dalam Hidayat, dkk., (2013), bahwa tanaman akan tumbuh dengan baik apabila unsur hara yang diberikan berada dalam jumlah yang seimbang dan sesuai dengan kebutuhan tanaman. Selain konsentrasi POC keong mas yang rendah pengaruh lain disebabkan oleh unsur $\mathrm{pH}$ tanah (Toe $d k k$., 2016). Menurut Gardner et al. (2008) bahwa pH tanah merupakan faktor utama yang mempengaruhi daya larut dan mempengaruhi ketersediaan nutrien tanaman, dan $\mathrm{pH}$ yang baik untuk pertumbuhan tanaman adalah 6,0-7,0. Hasil analisa tanah yang digunakan sebagai media tanam saat penelitian menunjukkan $\mathrm{pH}$ tanah sebesar 7,4. Purbajanti (2012) menyatakan bahwa reaksi tanah (kemasaman, pH) berpengaruh pada pertumbuhan tanaman karena berpengaruh pada hara tertentu yang dibutuhkan oleh tanaman untuk bertumbuh. Ketersediaan Phospor (P) berkurang pada tanah masam karena ion Besi (Fe), Alumunium (Al) dan Mangan (Mn) pada tanah. Pada $\mathrm{pH}$ tinggi ketersediaan Molibdenum turun, $\mathrm{pH}$ asam maka $\mathrm{Al}$, Mn dan Fe tinggi, Al sangat toksik bagi tanaman. Pada $\mathrm{pH}$ tinggi (> 7) bentuk amoniak di permukaan tanah akan menguap.

Berdasarkan Tabel 1. pengaruh perlakuan terhadap pertambahan tinggi tanaman dapat dijelaskan bahwa interval pemberian POC berbahan baku keong mas 5 hari sekali (P5) memberikan hasil terbaik yaitu $22,01 \mathrm{~cm} /$ minggu, sedangkan interval pemberian POC sebelas hari sekali (P11) memberikan hasil terendah dengan 19,60 $\mathrm{cm} /$ minggu. Pada perlakuan P0 memperoleh hasil rata-rata tinggi tanaman rumput Pennisetum purpureum cv. Mott sebesar 177,4 cm lebih tinggi dari P9: 173,8 cm dan P11: 167,2 cm. Hasil tersebut masih terlihat lebih tinggi bila dibandingkan dengan hasil penelitian Lasamandi dkk., (2013) sebesar 108,2 cm untuk perlakuan kontrol, pada umur panen 42 hari dengan perlakuan yang dicobakan yaitu pertumbuhan dan perkembangan rumput Pennisetum purpureum cv. Mott yang diberi pupuk organik hasil fermentasi EM4. Rata-rata pertambahan tinggi tanaman rumput Pennisetum purpureum cv. Mott selama penelitian yaitu $20,90 \mathrm{~cm} /$ minggu sedangkan rerata tinggi tanaman rumput Pennisetum purpureum cv. Mott yang diukur pada umur pemanenan 60 hari sebesar $176,18 \mathrm{~cm}$.

Hasil analisis varians menunjukkan bahwa interval waktu pemberian POC berbahan baku keong mas tidak memberikan pengaruh nyata $(\mathrm{P}>0,05)$ terhadap pertambahan tinggi tanaman rumput Pennisetum purpureum cv. Mott. Tidak adanya perbedaan yang signifikan tersebut diakibatkan oleh ketersediaan unsur $\mathrm{N}, \mathrm{P}, \mathrm{K}$ dalam tanah kurang mencukupi kebutuhan tanaman untuk bertumbuh dan berkembangbiak. Ketersediaan unsur hara dalam tanah mempengaruhi pertumbuhan tanaman rumput Pennisetum purpureum cv. Mott. Pernyataan tersebut sesuai dengan pendapat Purbajanti (2012), bila suplai $\mathrm{N}$ tidak optimal maka pertumbuhan terhambat, $\mathrm{N}$ dimobilisasi dari daun tua ke daerah pertumbuhan baru. Sesuai pendapat dari Gardner et al. (2008), menjelaskan bahwa apabila ketersediaan unsur-unsur yang dibutuhkan tanaman berada dalam keadaan cukup, maka hasil metabolismenya akan membentuk protein, enzim, hormone dan karbohidrat, sehingga pembesaran, perpanjangan, dan pembelahan sel akan berlangsung dengan cepat. Marsono dan Lingga (2013) menjelaskan bahwa N dan $\mathrm{P}$ memiliki peran sebagai berikut: merangsang pertumbuhan secara keseluruhan, khususnya batang cabang dan daun; berperan dalam pembentukan klorofil untuk fotosintesis; merangsang pertumbuhan akar; membantu asimilasi dan pernapasan; mempercepat pembungaan dan pemasakan biji serta buah.

Berdasarkan Tabel 1. Pengaruh perlakuan terhadap bobot segar tanaman rumput Pennisetum purpureum cv. Mott menjelaskan bahwa perlakuan dengan interval waktu pemberiaan POC keong mas 5 hari sekali (P5) memberikan hasil terbaik sebesar $57,71 \mathrm{ton} / \mathrm{ha}$ atau $57.710 \mathrm{~kg} / \mathrm{ha}$. Hal ini disebabkan oleh tingginya jumlah tunas dan pertambahan tinggi tanaman yang ternyata juga lebih tinggi pada perlakuan tersebut. Pernyataan tersebut sesuai dengan pendapat Syofiarni (1982) yang dikutip dalam Sari (2012) bahwa produksi selalu disebabkan adanya petumbuhan dari rumput seperti pertambahan tinggi tanaman dan jumlah anakan. Rata-rata produksi pada P5 (pemberian POC keong mas 5 hari sekali) 57,67 ton/ha, lebih rendah dari 
penelitian Khalidin, et al., (2013) mencapai 80,50 ton/ha ${ }^{-1}$, dengan perlakuan yang dicobakan yaitu aplikasi FMA pupuk kandang terhadap produksi dan kualitas rumput Pennisetum purpureum cv. Mott. Produksi bobot segar rumput Pennisetum purpureum cv. Mott pada perlakuan P0: 53,62 ton/ha terlihat lebih tinggi dari perlakuan P7: 49,39 ton/ha dan P11: 50,71 ton/ha. Hasil tersebut juga lebih tinggi jika dibandingkan dengan penelitian Kaca $d k k$., (2016) sebesar 46,35 ton/ha (perlakuan kontrol) pada umur panen 60-70 hari dengan perlakuan yang dicobakan yaitu produksi dan kualitas rumput Pennisetum purpureum cv. Mott yang ditanam dalam pertanaman campuran rumput dan legum pada pemotongan pertama. Rataan produksi akibat pengaruh perlakuan interval waktu pemberian POC keong mas terhadap produksi bobot segar rumput Pennisetum purpureum cv. Mott yaitu 53,32 ton/ha atau $53.320 \mathrm{~kg} / \mathrm{ha}$.

Berdasarkan hasil analisis sidik ragam menunjukkan bahwa interval waktu pemberian POC berbahan baku keong mas tidak memberikan pengaruh nyata $(\mathrm{P}>0,05)$ terhadap produksi bobot segar hijauan rumput Pennisetum purpureum cv. Mott. Hal ini dapat disebabkan oleh adanya curah hujan yang ada berpeluang menyebabkan pencucian hara dalam tanah sehingga ketersediaan unsur hara untuk pertumbuhan tanaman tidak tercukupi. Pernyataan tersebut didukung oleh pernyataan Rosmarkam dan Yuwono (2002) dikutip dalam Nandissa, dkk., (2012) menyatakan bahwa jika pencucian unsur sangat besar maka kehilangan unsur hara lebih besar dibandingkan pengambilan unsur hara oleh tanaman. Tabel 1. Menunjukan bahwa pengaruh interval waktu pemberian POC keong mas terhadap produksi bahan kering rumput Pennisetum purpureum cv. Mott yang memberikan hasil terbaik terdapat pada perlakuan P5 (interval waktu pemberian POC setiap 5 hari sekali). Hal ini karena pada P5 jumlah unsure hara yang diperoleh tanaman rumput Pennisetum purpureum cv. Mott lebih tinggi dari perlakuan lainnya. Jumlah hara yang lebih banyak ini akan meningkatkan pertumbuhan dan produksi tanaman pakan. Hal ini sesuai dengan pendapat Gardner et al. (2008) bahwa ketersediaan hara yang tinggi akan meningkatkan pertumbuhan dan produksi tanaman. Rerata produksi bahan kering rumput Pennisetum purpureum cv. Mott sebesar 7,73 ton/ha atau $7.727 \mathrm{~kg} / \mathrm{ha}$. Produksi bahan kering rumput Pennisetum purpureum cv. Mott pada perlakuan $\mathrm{P} 0: 7,72$ ton/ha terlihat lebih tinggi dari perlakuan P7: 7,17 ton/ha, P9: 7,68 ton/ha dan P11: 7,26 ton/ha. Hasil tersebut juga lebih tinggi jika dibandingkan dengan penelitian Sari, (2012) sebesar 2,72 ton/ha (perlakuan kontrol N, P, K tanpa CMA) dengan perlakuan yang dicobakan yaitu produksi dan nilai nutrisi rumput Pennisetum purpureum cv. Mott yang diberi pupuk N, P, K berbeda dan CMA pada lahan kritis tambang batubara. Tidak berpengaruhnya interfal waktu pemberian POC keong mas terhadap produksi bahan kering hijauan rumput Pennisetum purpureum cv. Mott juga diakibatkan oleh produksi berat segar hijauan yang juga tidak berbeda.

\section{KESIMPULAN}

Disimpulkan bahwa pertumbuhan dan produksi rumput Pennisetum purpureum cv. Mott tidak dipengaruhi oleh interval waktu pemberian POC keong mas.

\section{SARAN}

Disarankan bahwa pemberian POC keong mas sebaiknya perlu ditingkatkan jumlah dan konsentrasinya, sebaiknya ada yang meneliti lebih lanjut mengenai level penggunaan POC keong mas pada jenis hijaun lain, dan selain menggunakan tepung keong mas sebagai sumber $\mathrm{N}$ dalam pembuatan POC, dapat juga menggunakan sumber protein hewani lain seperti: tepung ikan, tepung daging dan lain-lain.

\section{DAFTAR PUSTAKA}

[1] Budidayapetani. 2015. Pengertian Rumput Odot Dan Manfaatnya untuk Ternak. http://www.budidayapetani.com/2015/12/pengertianrumput-odot-dan manfaatnya.html. Diakses pada: Senin, 13 Juni 2016.

[2] Djiwosaputro, D. 1990. Pengantar Fisiologi Tumbuhan. Gramedia, Jakarta.

Gardner, F.P., Pearce, R.B. dan Mitchell, R.L. 2008. Fisiologi Tanaman Budidaya. Terjemahan. UI Press. Jakarta.

[3] Gasperz, V. 1994. Metode Perancangan Percobaan. Penerbit $C V$. Armico. Bandung.

[4] Kaca I. N., Sutapa I. G., Suariani L., Tonga Y., Yudiastari N. M. dan Suwitari N. K. E. 2016. Produksi Dan Kualitas Rumput Gajah Kate (Pennisetum purpureum cv.Mott) Yang Ditanam Dalam 
Silvester Muga Sada, Bernadete Barek Koten, Bernadus Ndoen, Agustinus Paga, Paskalis Toe, RedemptaWea, Ariyanto. Pengaruh Interval Waktu Pemberian Pupuk Organik Cair Berbahan Baku Keong Mas Terhadap Pertumbuhan dan Produksi Hijauan Pennisetum purpureum cv. Mott

Pertanaman Campuran Rumput dan Legum Pada Pemotongan Pertama. Jurusan Peternakan Fakultas Pertanian Universitas Warmadewa. Denpasar.

[5] Khalidin, Mirza I, \& Azis A. 2013. Aplikasi FMA pupuk kandang terhadap roduksi dan kualitas rumput gajah (Pennisetum purpureum Schum). Jurnal Pastura "Journal of Tropical Forage Science". 3 (1): 17 - 20.

[6] Lasamadi R. D., Malalantang, S. S., Rustandi \& Anis S. D. 2013. Fakultas Peternakan, Universitas Sam Ratu Langi. Manado.

[7] Marsono \& Lingga, L. 2013. Petunjuk Penggunaan Pupuk, Penebar Swadaya. Jakarta.

[8] Purbajanti, E. D. 2012. Rumput dan Legum Sebagai Hijauan Makanan Ternak. Graha Ilmu. Jakarta.

[9] Rosmarkam, A \& Yuwono, N.W. 2002. Ilmu Kesuburan Tanah. Kanisius. Yogyakarta.

[10] Sari R. M. 2102. Produksi dan Nilai Nutrisi Rumput Gajah (Pennisetum purpureum) CV. Taiwan Yang Diberi Dosis Pupuk N, P, K Berbeda dan CMA Pada Lahan Kritis Tambang Batubara. Program Studi Ilmu Peternakan Pascasarjana, Universitas Andalas.Padang.

[11] Sutedjo, M.M \& Kartasapoetra, 1991. Pengantar Ilmu Pertanian. Rineka Cipta, Jakarta.

[12] Suktikno. E. 2011. Pembuatan pakan buatan ikan bandeng. Direktorat Jenderal Perikanan Budidaya Balai Besar Pengembangan Budidaya Air Payau Jepara.

[13] Syamsuddin, Hasan S, Budiman \& Asrianie A. 2015. Efek Pemberian Cendawan Mikoriza Terhadap Pertumbuhan dan Produksi Bahan Kering Rumput Pennisetum purpureum cv. Mott Dalam Kondisi Cekaman Kekeringan. Jurusan Nutrisi dan Makanan Ternak, Fakultas Peternakan, Universitas Hasanuddin. Makasar.

[14] Toe, P., B. B. Koten., R. Wea., J. S. Oematan \& B. Ndoen. 2016. Pertumbuhan dan Produksi Rumput Setaria (Setaria spacelata) Pada Berbagai Level Peberian Pupuk Organik Cair Berbahan Feses Babi. Jurnal Ilmu Ternak, Desember 2016, Vol.16,No.2 Hal: 20.

[15] Yasin, M., Malik, M.A. \& N aZir , M.s. 2003. Effect of different spatial arrangements on forage yield, yield components and quality of Mott elephantgrass. Pakistan Journal of Agronomy, 2 (1), 52-58. 